\title{
Influence of cultivar, growth altitude and maturity stage on banana volatile compound composition
}

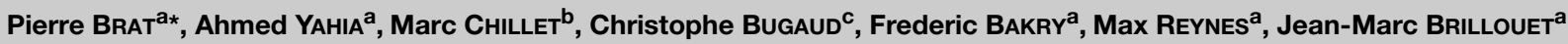

a Centre de coopération internationale en recherche agronomique pour le développement (Cirad), Département Flhor, TA 50 / PS4, Bld. De la Lironde, 34398 Montpellier Cedex 5 ,

France

brat@cirad.fr

${ }^{b}$ Cirad-Flhor,

Station de Neufchâteau, 97130 Capesterre-Belle-Eau, Guadeloupe, France

${ }^{\mathrm{c}}$ Cirad-Flhor, BP 153 , 97202 Fort-de-France, Martinique, France

${ }^{*}$ Correspondence and reprints

Received 25 September 2003 Accepted 3 March 2004

Fruits, 2004, vol. 59, p. 75-82 (C) 2004 Cirad/EDP Sciences All rights reserved DOI: $10.1051 /$ fruits:2004007

RESUMEN ESPAÑoL, p. 82

\section{Influence of cultivar, growth altitude and maturity stage on banana volatile compound composition.}

Abstract - Introduction. The quantitative volatile compound composition of bananas (Musa acuminata, AAA group, Cavendish subgroup) was investigated in two different cultivars (Robusta and Grande Naine) grown at two different altitudes [(90 and 500) $\mathrm{m}$ ], and ripened at two different maturity stages (color grades 5 and 7). Materials and methods. Volatile compounds were separated and identified by coupled capillary gas liquid chromatography / mass spectrometry. After evaluating changes in volatile composition during ripening, the effect of both growth altitude and cultivar was examined. Results and discussion. For a partially mature fruit, the growth altitude showed different effects on the two cultivars. The Robusta cv. exhibited a higher aroma volatile compound concentration at high altitude, while that of the Grande Naine cv. was higher at low altitude. At the fully mature stage, this difference still existed but was not so distinct. Conclusion. Whatever the ripening stage, Robusta cv. exhibited the highest aroma volatile compound concentration. Discriminate sensory analysis closely related to differences in the volatile composition of samples.

France / Guadeloupe / Musa (bananas) / aromatic compounds / altitude / maturity
Influence du cultivar, de l'altitude de la bananeraie et du stade de maturité sur la composition en composés volatils de la banane.

Résumé - Introduction. La composition quantitative en composés volatils de bananes (Musa acuminata, groupe AAA, sous-groupe Cavendish) a été étudiée pour deux cultivars différents (Robusta et Grande Naine) développés à deux altitudes différentes [(90 et 500) m] et à deux stades de maturité différents (notation 5 et 7 dans l'échelle de coloration). Matériel et méthodes. Des composés volatils ont été séparés et conjointement identifiés par chromatographie capillaire en gaz liquide et spectrométrie de masse. Après évaluation des changements en composés volatils intervenus pendant la maturation, les effets de l'altitude des plantations et du cultivar utilisé ont été examinés. Résultats et discussion. Pour un fruit partiellement mûr, l'altitude a eu différents effets sur les deux cultivars. La concentration en composés aromatiques volatils du cultivar Robusta a été la plus élevée en haute altitude, alors que celle de Grande Naine l'a été à basse altitude. Au stade de pleine maturité, cette différence était encore décelable, sans être aussi distincte. Conclusion. Quel que soit le stade de maturation, le cultivar Robusta a montré la concentration en composés aromatiques volatils la plus élevée. L'analyse sensorielle discriminante a été étroitement liée aux différences de composition en composés volatils des échantillons.

France / Guadeloupe / Musa (bananes) / composé aromatique / altitude / maturité 


\section{Introduction}

Bananas are the third most consumed fruit in the world, after citrus fruits and grapes, with more than 74 million tons produced in 2000 [1]. European consumption is mainly limited to the subgroup Cavendish (Musa acuminata, AAA group) with the major cultivars Dwarf Cavendish, Grande Naine and Robusta [2]. Analytical research on the aroma compounds of this fruit has been carried out for more than 30 years [3], and the quantitative composition of the volatile compounds of different cultivars is now widely known and reviewed [4]. Irrespective of the method used (e.g., static or dynamic headspace, or solvent extraction), the major volatile compounds are generally esters (isoamyl, isobutyl, and other uncommon esters), most of which are responsible for the fruity aroma [3, 5, 6], alcohols (pentan-2-ol, 3-methyl butanol) and ketones (pentan-2-one) [3, 7, 8].

The production of volatiles during ripening of bananas was studied by Macku and Jennings [9] who concluded that the total amount of banana volatiles followed a sigmoidal increase during ripening. Volatile composition is nevertheless highly dependent on geographical factors, as indicated by Cano et al. [10] and Shiota [3], who studied the influence of the area of cultivation. These latter authors highlighted how Cavendish bananas cultivated in Taiwan had a poorer appearance but stronger aroma and sweeter taste than those of the Philippines. It has been suggested on an empirical basis that, for a given cultivar at comparable maturity stages, bananas cultivated at a high altitude may have sensory characteristics different from those cultivated on a plain. To our knowledge, no comparative study on the influence of the growing altitude on sensory characteristics of banana has ever been conducted.

Two banana cultivars (Robusta and Grande Naine) were harvested at the 3/4 full stage [11] from open fields located on the plain, and in the hills in the French West Indies. Because bananas are preferentially consumed in the European market at color grades 5 and 7 , the fruits were then matured up to these stages, and their volatile compound compositions were measured. Trian- gular difference tests were performed to discriminate the fruits.

\section{Materials and methods}

\subsection{Plant materials}

The fruit studied were bananas (Musa acuminata) from the AAA group, Cavendish subgroup [12], cultivated on four open fields in Guadeloupe (French West Indies, France). Two of the fields chosen were located in close proximity to one another on the plain in Bois Debout (altitude $90 \mathrm{~m}$; average rainfall $2500 \mathrm{~mm}$ per annum; temperature 25$26^{\circ} \mathrm{C}$ ), and planted with Robusta (syn. Poyo), and Grande Naine (syn. Granda Enana) cultivars. The two other fields were located close to each other in a hilly area in Grand Marigot (altitude $500 \mathrm{~m}$; average rainfall $3500 \mathrm{~mm}$ per annum; average temperature $22-23^{\circ} \mathrm{C}$ ), and planted with the same cultivars.

Three banana bunches were randomly harvested at the 3/4 full stage [11] from each field; the hands were separated and placed in cardboard boxes which were then shipped $\left(14{ }^{\circ} \mathrm{C}\right)$ and delivered to an industrial ripening depot (Cavaillon, France) where they were ethylene-ripened to color grades 3-4 [13]. Each batch was then further ripened on the bench at $20{ }^{\circ} \mathrm{C}$ to color grade 5 (yellow with green tips) and color grade 7 (flecked) [13]. The fruits were then stored at $(14 \pm$ 1) ${ }^{\circ} \mathrm{C}$, and $85-90 \%$ relative humidity [10] until being analyzed. Finally, fingers were randomly selected from each batch and all analyses including sensory study were carried out immediately after slicing.

\subsection{Solvents and chemicals}

Reference compounds, if available, and $n$ alkane $\left(\mathrm{C}_{5}-\mathrm{C}_{27}\right)$ standards were from Aldrich Chimie (Saint-Quentin Fallavier, France). All chemicals and solvents ( $n$-pentane and ether) were of analytical grade.

\subsection{Extraction of volatile compounds}

Three randomly picked fingers from each batch were finely sliced separately after 
peeling and then crushed in a Waring blender (Waring, US). A pureed sample ( $5 \mathrm{~g}$ ) was mixed with $5 \mathrm{~mL}$ of distilled water; then $n$-decanal $(8.6 \mu \mathrm{g})$ was added as internal standard, followed by $50 \mathrm{~mL}$ of pentane / ether (1:1). The slurry was finally homogenized with a Potter Elvejhem homogenizer for $5 \mathrm{~min}$. Phase separation was achieved by centrifugation at $9000 \mathrm{~g}$ for $5 \mathrm{~min}$. The upper organic phase was recovered, dried over anhydrous sodium sulfate, and finally concentrated at $37{ }^{\circ} \mathrm{C}$ with a $25 \mathrm{~cm}$ Vigreux distillation column to a volume of $2 \mathrm{~mL}$.

\subsection{GC-MS analysis}

A Hewlett-Packard 6890 gas chromatograph coupled to a Hewlett-Packard 5973 quadrupole mass spectrometer was used, with electron ionization mode (EI) generated at $70 \mathrm{eV}$. The ion source and quadrupole temperatures were $230{ }^{\circ} \mathrm{C}$ and $150{ }^{\circ} \mathrm{C}$, respectively, and the filament emission current was $1 \mathrm{~mA}$. Volatile compounds were separated on a DB-Wax (column A, J\&W Scientific, Folsom, CA, USA) fused silica capillary column $(30 \mathrm{~m} \times 0.25 \mathrm{~mm}$ i.d. $\times 0.25 \mu \mathrm{m}$ film $)$ and on a DB-1 (column B, J\&W Scientific, Folsom, CA, USA) fused silica capillary column $(30 \mathrm{~m} \times 0.25 \mathrm{~mm}$ i.d. $\times 0.25 \mu \mathrm{m}$ film). Oven temperature was increased from $40{ }^{\circ} \mathrm{C}$ at a rate of $3{ }^{\circ} \mathrm{C} \cdot \mathrm{min}^{-1}$ up to $250^{\circ} \mathrm{C}$ where it was held for $20 \mathrm{~min}$. The on-column injector was heated from $20^{\circ} \mathrm{C}$ to $245^{\circ} \mathrm{C}$ at $180^{\circ} \mathrm{C} \cdot \mathrm{min}^{-1}$. Detector temperature was $245^{\circ} \mathrm{C}$. Helium was the carrier gas at a flow of $1.1 \mathrm{~mL} \cdot \mathrm{min}^{-1}$. Electron impact mass spectra were recorded in the 40-600 amu range at $1 \mathrm{~s} \cdot$ interval $^{-1}$. Injected volumes were $1 \mu \mathrm{L}$ of concentrated extract. Compounds were identified on the basis of linear retention indices on both columns (DB-Wax, and DB-1) [14] and EI mass spectra (Wiley 275.L library) from the literature or from authentic standard compounds. Since our aim was to measure the concentration of volatiles in each fraction, amounts are expressed as $\mu \mathrm{g} n$-decanal equivalent $100 \mathrm{~g}^{-1}$ fresh weight, response factors being taken as 1.0 for all compounds with reference to the internal standard. Linear retention indices were calculated with reference to $n$-alkanes $\left(\mathrm{C}_{5}-\mathrm{C}_{27}\right)$. Concentrations are given as the average of triplicates.

\subsection{Taste panel procedure}

Samples (10 g) of fresh pulp were laced into three-digit randomly coded plates and equilibrated at room temperature until presentation to the panellists. Triangle difference tests were conducted in a sensory analysis testing laboratory by an expert eighteenmember panel to detect the sensory differences between samples. They were therefore asked to taste samples at the 5 and 7 ripening stages, successively, according to growth altitude [(Robusta on plain / Robusta in hills) and (Grand Naine on plain / Grande Naine in hills)] and cultivar effects [(Robusta on plain / Grande Naine on plain) and (Robusta in hills / Grande Naine in hills)]. Training and tasting procedures generally followed those described by French Norm AFNOR [15, 16]. Flavor discrimination trials were carried out under red light, and no attempt to describe or compare the quality of the bananas was undertaken, as this is highly subjective and dependent on a wide range of factors.

\subsection{Statistical analysis}

The Pascal Schilch risk table was used to identify significant differences between samples. For an eighteen-member panel, the significant difference was calculated to be 11 and 10 correct answers at $P<0.01$ and $P<0.05$, respectively (table $I$ ).

\section{Results and discussion}

\subsection{Changes in volatile composition during ripening}

Volatile compounds were extracted by the azeotropic mixture pentane/ether (1:1) from fruits of the two cultivars at two different ripening stages, each cultivated at two different altitudes (table I). Each sample was extracted in triplicate and analyzed by GC-MS. The range in standard deviations (sd) according to concentration range were as follows: (520) $\mu \mathrm{g} \cdot 100 \mathrm{~g}^{-1}$ fresh weight, sd: (20-26)\%; (20-200) $\mu \mathrm{g} \cdot 100 \mathrm{~g}^{-1}$ fresh weight, sd: (1420)\%; (200-500) $\mu \mathrm{g} \cdot 100 \mathrm{~g}^{-1}$ fresh weight, sd: (8-13)\%; (500-1000) $\mu \mathrm{g} \cdot 100 \mathrm{~g}^{-1}$ fresh weight, 
Table I.

Volatile compounds ( $\mu \mathrm{g} \cdot 100 \mathrm{~g}^{-1}$ fresh weight) recovered from two banana cultivars (Robusta and Grande Naine) at two maturity stages (color grades 5 and 7 ), and at two different growth altitudes (plain and hilly area) (Guadeloupe, French West Indies, France).

\begin{tabular}{|c|c|c|c|c|c|c|c|c|c|c|c|c|}
\hline \multicolumn{2}{|c|}{ Volatile compounds } & \multirow{2}{*}{\multicolumn{2}{|c|}{$\begin{array}{l}\text { Linear retention index } \\
\text { from }\end{array}$}} & \multicolumn{4}{|c|}{ Color grade 5} & \multicolumn{4}{|c|}{ Color grade 7} & \multirow{3}{*}{$\begin{array}{c}\text { Key } \\
\text { for } \\
\text { R.I. }^{1}\end{array}$} \\
\hline & & & & \multicolumn{2}{|c|}{ Robusta } & \multicolumn{2}{|c|}{ Giant } & \multicolumn{2}{|c|}{ Robusta } & \multicolumn{2}{|c|}{ Giant } & \\
\hline & & DB-Wax & Literature & Plain & Hills & Plain & Hills & Plain & Hills & Plain & Hills & \\
\hline \multirow[t]{3}{*}{ Aldehydes } & hexanal & 1063 & 1065 & 48 & 27 & 28 & 19 & traces $^{e}$ & 0 & 19 & 0 & 1 \\
\hline & $(E)$-hex-2-enal & 1189 & 1202 & 68 & 47 & 36 & 38 & 19 & 6 & 20 & 14 & 1 \\
\hline & nonanal & 1367 & 1374 & 2 & 3 & 3 & 3 & 4 & 2 & 3 & 3 & 1 \\
\hline \multirow[t]{3}{*}{ Ketones } & pentan-2-one & 987 & 969 & traces & 89 & 30 & 19 & 426 & 341 & 306 & 223 & 1 \\
\hline & heptan-2-one & 1160 & 1160 & 0 & 15 & 3 & 0 & 49 & 26 & 43 & 21 & 2 \\
\hline & (Z)-hept-4-en-2-one & 1222 & 1228 & 0 & 18 & 4 & 0 & 58 & 16 & 49 & 19 & 2 \\
\hline \multirow[t]{8}{*}{ Alcohols } & 2-methyl propanol & 1078 & 1060 & 5 & 28 & 3 & 3 & 121 & 200 & 56 & 148 & 1 \\
\hline & pentan-2-ol & 1105 & 1221 & 4 & 73 & 32 & 23 & 464 & 305 & 257 & 177 & 1 \\
\hline & butanol & 1126 & 1103 & 19 & 31 & 15 & 10 & 68 & 101 & 76 & 83 & 1 \\
\hline & 3-methyl butanol & 1183 & 1168 & 33 & 180 & 22 & 25 & 353 & 350 & 185 & 291 & 2 \\
\hline & (Z)-hept-4-en-2-ol & 1311 & 1302 & 7 & 17 & 4 & 3 & 57 & 17 & 42 & 22 & 2 \\
\hline & hexanol & 1323 & 1331 & 64 & 47 & 75 & 35 & 35 & 39 & 46 & 33 & 1 \\
\hline & (Z)-hex-3-enol & 1331 & 1351 & 2 & 0 & 1 & 1 & 4 & 6 & 4 & 5 & 2 \\
\hline & (Z)-hex-4-enol & 1389 & 1382 & 16 & 0 & 3 & 2 & 4 & 16 & 3 & 12 & 2 \\
\hline \multirow[t]{10}{*}{ Esters } & ethyl acetate & 922 & 872 & 0 & 9 & 5 & 8 & 12 & 51 & 33 & 38 & 1 \\
\hline & isobutyl acetate & 1016 & 1010 & 7 & 30 & 6 & 5 & 232 & 431 & 122 & 500 & 2 \\
\hline & butyl acetate & 1064 & 1059 & 18 & 23 & 8 & 6 & 76 & 171 & 135 & 153 & 1 \\
\hline & 2-pentyl acetate & 1067 & 1161 & 4 & 68 & 38 & 20 & 538 & 418 & 476 & 395 & 2 \\
\hline & isoamyl acetate & 1108 & 1110 & 34 & 178 & 31 & 20 & 469 & 652 & 385 & 724 & 1 \\
\hline & isobutyl butanoate & 1144 & 1139 & traces & 21 & 3 & 2 & 104 & 255 & 46 & 153 & 2 \\
\hline & $\begin{array}{c}\text { isoamyl } \\
\text { isobutanoate }\end{array}$ & 1194 & 1187 & traces & 14 & 6 & 5 & 183 & 148 & 125 & 55 & 2 \\
\hline & butyl butanoate & 1197 & 1207 & 0 & 27 & 12 & 10 & 82 & 104 & 117 & 92 & 1 \\
\hline & isoamyl butanoate & 1244 & 1242 & traces & 183 & 32 & 26 & 401 & 549 & 259 & 412 & 1 \\
\hline & isoamyl isovalerate & 1274 & 1287 & 0 & 24 & 0 & 0 & 103 & 139 & 31 & 0 & 2 \\
\hline \multirow{7}{*}{$\begin{array}{l}\text { Carboxylic } \\
\text { acids }\end{array}$} & acetic acid & 1399 & 1410 & 64 & 24 & 36 & 36 & 80 & 83 & 48 & 62 & 1 \\
\hline & propanoic acid & 1490 & 1504 & 5 & 5 & 6 & 4 & 16 & 74 & 0 & 0 & 1 \\
\hline & isobutanoic acid & 1515 & 1535 & 0 & 0 & 0 & 0 & 20 & 54 & 0 & 45 & 2 \\
\hline & butanoic acid & 1580 & 1588 & 9 & 26 & 31 & 46 & 60 & 61 & 39 & 58 & 1 \\
\hline & isovaleric acid & 1625 & 1636 & 13 & 38 & 58 & 46 & 86 & 63 & 27 & 52 & 2 \\
\hline & hexanoic acid & 1802 & 1795 & 22 & 36 & 34 & 24 & 61 & 40 & 68 & 0 & 1 \\
\hline & octanoic acid & 2012 & 2008 & 3 & 0 & 1 & 6 & 2 & 4 & 3 & 0 & 2 \\
\hline \multirow{3}{*}{$\begin{array}{l}\text { Phenolether } \\
\text { derivatives }\end{array}$} & eugenol & 2099 & 2115 & 84 & 42 & 41 & 7 & 163 & 246 & 194 & 314 & 1 \\
\hline & elimicine & 2166 & 2150 & 30 & 110 & 55 & 70 & 273 & 271 & 563 & 317 & 2 \\
\hline & 5-methoxyeugenol & 2390 & - & 309 & 924 & 406 & 387 & 898 & 873 & 1096 & 1196 & 2 \\
\hline \multicolumn{2}{|c|}{$\begin{array}{l}\text { Total concentrations } \\
\left(\mu \mathrm{g} \cdot 100 \mathrm{~g}^{-1} \text { fresh weight) }\right.\end{array}$} & - & - & 867 & 2356 & 1067 & 908 & 5514 & 6111 & 4876 & 5618 & - \\
\hline
\end{tabular}




\begin{tabular}{|c|c|c|c|}
\hline \multirow[t]{2}{*}{ Factor considerec } & & \multicolumn{2}{|c|}{ Color grade significance } \\
\hline & & 5 & 7 \\
\hline \multirow[t]{2}{*}{$\begin{array}{l}\text { Growth altitude } \\
\text { effect }\end{array}$} & $\begin{array}{l}\text { Robusta on the plain / } \\
\text { Robusta in the hills }\end{array}$ & ** & ** \\
\hline & $\begin{array}{l}\text { Grande Naine on the plain / } \\
\text { Grande Naine in the hills }\end{array}$ & ** & ns \\
\hline \multirow[t]{2}{*}{ Cultivar effect } & $\begin{array}{l}\text { Robusta on the plain / } \\
\text { Grande Naine on the plain }\end{array}$ & ns & $\star \star$ \\
\hline & $\begin{array}{l}\text { Robusta in the hills / } \\
\text { Grande Naine in the hills }\end{array}$ & ** & * \\
\hline
\end{tabular}

sd: (6-10)\%; (1000-2000) $\mu \mathrm{g} \cdot 100 \mathrm{~g}^{-1}$ fresh weight, sd: (4-8)\%. The most polar compounds (acetic acid and ethyl acetate) may be underestimated due to their higher solubility in the water phase than in the azeotropic mixture [17].

According to Macku and Jennings [9], whatever the cultivars and the growth altitude, most volatile compounds (i.e., ketones, alcohols, esters and carboxylic acids) increased in concentration during ripening. Esters (mainly 2-pentyl, isoamyl and isobutyl acetates, and isoamyl butanoate and isobutanoate) probably cause the specific fruity aroma found in banana [3], and increase enormously during ripening [e.g., Robusta cultivar on the plain (63 to 2198) $\mu \mathrm{g} \cdot 100 \mathrm{~g}^{-1}$ ]. Tressl and Jennings [18] had already noted this behavior for all except 2-pentyl acetate. These authors also observed that the cycle for the acetate esters was out-of-phase with that observed for the butyrates (these esters probably not having a common precursor).

Alcohols (mainly pentan-2-ol, 3-methyl butanol and 2-methyl propanol) would also contribute to the succulent character of banana aroma [3], and their concentrations are from two to seven times higher at color grade 7 than grade 5 . Pentan-2-one is one of the major volatile compounds of bananas, possessing a banana-like flavor at concen- trations below 50 ppm [19]. It was poorly recovered at color grade 5 and was found at concentrations ranging from (223 to 426) $\mu \mathrm{g} \cdot 100 \mathrm{~g}^{-1}$ in fully mature fruit.

As previously reported by Miranda et al. [20], the full-bodied and mellow aroma of ripe bananas has been associated with phenolether derivatives (typically eugenol, 5-methoxyeugenol and elimicine) which probably originate from phenylalanine and caffeic acid precursors and are found at concentrations four to five times higher at color grade 7 than at color grade 5 . In contrast, the concentrations in the banana puree of the two major aldehydes, hexanal, and $(E)$ hex-2-enal, decline during ripening, these two compounds possessing pungent fatty, green, and grassy odors (flavor thresholds in water of 0.3 and $4.9 \mu \mathrm{g} \cdot 100 \mathrm{~g}^{-1}$, respectively) [21].

\subsection{Growth altitude effects on volatile composition}

At color grade 5, the fruit of the Robusta cv. cultivated in the hills exhibit higher concentrations of ketones [(122 against 0$) \mu \mathrm{g} \cdot 100 \mathrm{~g}^{-1}$ ], alcohols [(376 against 150) $\mu \mathrm{g} \cdot 100 \mathrm{~g}^{-1}$ ], esters [(577 against 63) $\left.\mu \mathrm{g} \cdot 100 \mathrm{~g}^{-1}\right]$ and phenolether derivatives [1076 against 423) $\mu \mathrm{g} \cdot 100 \mathrm{~g}^{-1}$ ] than fruit cultivated on the plain (table I). 
The only exceptions are aldehyde compounds with grassy odors, and carboxylic acids. Of the eight alcohols measured, 3methyl butanol is present in the Robusta $\mathrm{cv}$. sample grown in a hilly area at a much higher concentration than its retronasal odor threshold in water (180 vs. $25 \mu \mathrm{g} \cdot 100 \mathrm{~g}^{-1}$ ) [22]. Whatever the growth altitude at color grade 5, the fruit of the Grande Naine cv. showed similar concentrations of the various groups of volatiles (Giant on the plain Giant in the hills). These data were in agreement with the triangular test results (table II) for fruits of the Robusta cv. cultivated on the plain and in the hills which were found to be significantly different at grade 5; conversely, equivalent fruits from the Grande Naine cv. (on the plain or in the hills) were also found to be different, although their volatile compounds' distribution was similar.

Whatever the cultivar, the concentration of ester compounds at grade 7 was found to be in good agreement with the data of Jordán et al. [7] quantifying isoamyl acetate and butanoate at $(485 \pm 138) \mu \mathrm{g} \cdot 100 \mathrm{~g}^{-1}$ and $(713 \pm 123) \mu \mathrm{g} \cdot 100 \mathrm{~g}^{-1}$, respectively (table I).

The major differences observed in the case of the fruit of the Robusta $\mathrm{cv}$. at grade 5 were not so obvious at color grade 7 . Except for esters, which were still found in higher concentrations in the fruit of the Robusta and Grande Naine cvs. cultivated in the hills with regard to those cultivated on the plain [(2919 against 2198) $\mu \mathrm{g} \cdot 100 \mathrm{~g}^{-1}$ and (2522 against 1730) $\mu \mathrm{g} \cdot 100 \mathrm{~g}^{-1}$, respectively], and ketones, which showed a reverse behavior, other groups of volatiles were found in similar concentrations. These differences at both ripening stages were corroborated by the sensory analysis. The panel significantly discriminated between the two batches at $P<0.01$ (table II).

\subsection{Cultivar effects on volatile composition}

A comparison of the Robusta and Grande Naine cvs. at color grade 5 when cultivated at low altitude produces mixed results. The Grande Naine cv. is characterized by higher proportions of ketones (none was identi- fied in the Robusta cv.), esters (mainly 2pentyl acetate and isoamyl butanoate), and carboxylic acids than the Robusta cv. but a lower proportion of aldehydes [(67 against 117) $\mu \mathrm{g} \cdot 100 \mathrm{~g}^{-1}$ ] (table I). Phenolether derivatives, that are responsible for the mellow aroma, and alcohols, that relate to the fruity notes of bananas, are present in similar amounts in both cvs. For fruits cultivated in the hills, at grade 5, the Robusta cv. was richer in ketones, alcohols and esters than the Grande Naine cv., and these fruits were actually discriminated by the triangular difference test (table II).

At color grade 7, contrasting differences were observed with the Robusta $\mathrm{cv}$. on the plain possessing higher proportions of ketones, esters, and especially alcohols, which were present at a concentration about two times higher than that of the Grande Naine cv. When cultivated in the hills, the fruit of the Robusta cv. showed higher levels of ketones, alcohols and carboxylic acids than those of the Grande Naine cv., lower levels of phenolether derivatives, and similar amounts of esters. Again, these fruits were discriminated at $P<0.05$ (table II).

\section{Conclusion}

Differences in the volatile composition of samples (i.e., Robusta and Grande Naine crs. on the plain and in the hills) at both color grades 5 and 7 were generally reflected in sensorial differences. At color grade 5, the growth altitude has differing effects on the two cvs.: the concentration of volatile compounds of Robusta $\mathrm{CV}$. is higher at high altitude while that of Grande Naine cv. shows no significant difference whatever the growth altitude. When cultivated in the hills, the Robusta cv. exhibits a higher aroma concentration than the Grande Naine cv. These differences were similar, if less distinct, for fully mature fruit. These results clearly indicate that, whatever the ripening stage, the Robusta cv. grown at a high altitude possesses the highest concentrations of volatile compounds [(2356 and 6111) $\mu \mathrm{g} \cdot 100 \mathrm{~g}^{-1}$ at color grades 5 and 7 , respectively]. 


\section{Acknowledgments}

The authors acknowledge the Groupement de Producteurs de Bananes Guadeloupe, Région Guadeloupe, ODEADOM, and European Union for their financial support.

\section{References}

[1] Lescot T., Banane. Production, commerce et varieties, FruitTrop 87 (2002) 7-11.

[2] Champion J., Les triploïdes AAA, in: Champion J. (Ed.), Notes et documents sur les bananiers et leur culture, Institut Français de Recherches Fruitières Outre-Mer, SETCO, Paris, 1967, pp. 62-78.

[3] Shiota H., New esteric components in the volatiles of banana fruit (Musa sapientum L.), J. Agric. Food Chem. 41 (1993) 2056-2062.

[4] Anonymous, Banana (Musa sapientum L.), in: Maarse H. (Ed.), Volatile compounds in food. Qualitative and quantitative data, TNO Nutrition and Food Research Institute AJ Zeist, The Netherlands, 1996, pp. 3.1-3.5.

[5] Tressl R., Drawert F., Heimann W., Emberger R., Über die biogenese von aromastoffen bei pflanzen und früchten, Z. Lebensm. Unters. Forsch. 142 (1970) 313-317.

[6] McCarthy A.I., Palmer J.K., Shaw C.P., Anderson E.E., Correlation of gas chromatographic data with flavour profiles of fresh banana fruit, J. Food Sci. 28 (1963) 379-384.

[7] Jordán M.J., Tandon K., Shaw P.E., Goodner K.L., Aromatic profile of aqueous banana essence and banana fruit by gas chromatography-mass spectrometry (GC-MS) and gas chromatography-olfactometry (GC-O), J. Agric. Food Chem. 49 (2001) 4813-4817.

[8] Pérez A.G., Cert A.R., Rios J.J., Olias J.M., Free and glycosidically bound volatile compounds from two banana cultivars: Valery and Pequena enana, J. Agric. Food Chem. 45 (1997) 4393-4397.

[9] Macku C., Jennings W., Production of volatiles by ripening bananas, J. Agric. Food Chem. 35 (1987) 845-848.

[10] Cano M.P., de Ancos B., Matallana C., Cámara M., Reglero G., Tabera J., Differences among Spanish and Latin-American banana cultivars: morphological, chemical, and sensory characteristics, Food Chem. 59 (1997) 411-419.

[11] Ganry J., Recherche d'une méthode d'estimation de la date de récolte du bananier à partir de données climatiques, dans les conditions des Antilles, Fruits 33 (1978) 669-680.

[12] Purseglove J.W., Musaceae, in: Purseglove J.W. (Ed.), Tropical crops monocotyledons, Part I, Longman, London, 1974, pp. 344-384.

[13] Von Loesecke H.W., Bananas, in: Von Loesecke H.W. (Ed.), Bananas, Interscience, NY, USA, 1950, pp. 108-109.

[14] Jennings W., Shibamoto T., Compounds and their retention indices, in: Jennings W., Shibamoto T. (Eds.), Qualitative analysis of flavor and fragrance volatiles by glass capillary gas chromatography, Academic Press, NY, USA, 1980, pp. 29-57.

[15] Anonymous, Analyse sensorielle. Guide général pour la sélection, l'entraînement et le contrôle des sujets. Partie 1 : sujets qualifiés, French Norm AFNOR, ISO 8586-1, 1993.

[16] Anonymous, Analyse sensorielle - Méthodologie - Essai triangulaire, French Norm AFNOR V 09-013, 1983.

[17] Brat P., Rega B., Alter P., Reynes M., Brillouet J.-M., Distribution of volatile compounds in the pulp, cloud, and serum of freshly squeezed orange juice, J. Agric. Food Chem. 51 (2003) 3442-3447.

[18] Tressl R., Jennings W.G., Production of volatile compounds in the ripening banana, J. Agric. Food Chem. 20 (1972) 189-192.

[19] Arctander S., Methyl propyl ketone, in: Arctander S. (Ed.), Perfume and flavor chemicals (aroma chemicals), Montclair, US, No. $2226,1969$.

[20] Miranda E.J.F., Nogueira R.I., Pontes S.M., Rezende C.M., Odour-active compounds of banana passa identified by aroma extract dilution analysis, Flav. Fragr. J. 16 (2001) 281-285.

[21] Ahmed E., Dennison R.A., Dougherty R.H., Shaw, P.E., Flavor and odor thresholds in water of selected orange juice components, J. Agric. Food Chem. 26 (1978) 187-191.

[22] Buettner A., Schieberle P., Evaluation of aroma differences between hand-squeezed juices from Valencia late and Navel oranges by quantitation of key odorants and flavor reconstitution experiments, J. Agric. Food Chem. 49 (2001) 2387-2394. 


\section{Influencia del cultivar, de la altitud de la plantación y del estado de madurez en la composición de compuestos volátiles del banano.}

Resumen - Introducción. Se estudió la composición cuantitativa de compuestos volátiles de bananos (Musa acuminata, grupo AAA, subgrupo Cavendish) en dos cultivares diferentes (Robusta y Gran Enana) cultivados en dos altitudes diferentes [(90 y 500) $\mathrm{m}$ ] y en dos fases de madurez diferentes ( 5 y 7 puntos en la escala de Von Loesecke). Material y métodos. Se separaron los compuestos volátiles y se identificaron conjuntamente mediante cromatografía capilar de gas-líquido y espectrometría de masas. Tras la evaluación de los cambios de compuestos volátiles producidos durante la maduración, se examinaron los efectos de la altitud de las plantaciones y del cultivar utilizado. Resultados y discusión. En fruta parcialmente madura, la altitud tuvo distintos efectos en ambos cultivares. La concentración de compuestos aromáticos volátiles del cultivar Robusta fue la más elevada en alta altitud, mientras que la de Gran Enana lo fue en baja altitud. En el estado de plena madurez, esta diferencia era aún perceptible, sin ser tan marcada. Conclusión. Cualquiera que sea el estado de maduración, el cultivar Robusta mostró la concentración más alta de compuestos aromáticos volátiles. El análisis sensorial discriminante estuvo estrechamente ligado a las diferencias de composición de compuestos volátiles de las muestras.

Francia / Guadalupe / Musa (bananos) / compuestos aromáticos / altitud / madurez

To access this journal online: www.edpsciences.org 